\title{
APLIKASI SISTEM PENDUKUNG KEPUTUSAN ANALISIS KELAYAKAN PEMBERIAN KREDIT MENGGUNAKAN METODE SAW PADA PERUSAHAAN LEASING
}

\author{
Siti Aisyah ${ }^{1}$, Windania Purba ${ }^{2}$
}

Address: Universitas Prima Indonesia / Fakultas Teknologi dan Ilmu Komputer, Sistem Informasi, Indonesia ${ }^{1}$, Universitas Prima Indonesia / Fakultas Teknologi dan Ilmu Komputer, Sistem Informasi, Indonesia².

Email: sitiaisyah@unprimdn.ac.id*

\begin{abstract}
Abstrak
Salah satu masalah aktual yang dihadapi oleh perusahaan leasing dalam memberikan kredit kepada pelanggan mereka adalah risiko kredit macet. Untuk mengatasi masalah ini, aplikasi berbasis sistem pendukung keputusan, yang memfasilitasi pendekatan yang lebih baik dalam menentukan kelayakan memberikan wawasan yang lebih mendalam tentang kemampuan pelanggan, dapat menjadi solusi. Salah satu metode yang tersedia untuk digunakan adalah Simple Additive Weighting (SAW). Metode ini memungkinkan perhitungan nilai untuk menentukan kelayakan suatu permintaan. Konsep dasar SAW adalah untuk mengetahui jumlah kinerja tertimbang di setiap alternatif. Faktor atau kriteria yang digunakan dalam penelitian ini meliputi disiplin pelanggan, jumlah uang muka, pendapatan bulanan, jaminan kredit, dan status tempat tinggal. Pada lingkup akademik, penelitian ini juga dapat digunakan sebagai pengayaan bahan ajar terutama dalam kursus Sistem Pendukung Keputusan serta sistem informasi secara umum. Hasil penelitian ini juga diharapkan menjadi salah satu referensi bagi siswa dalam menerapkan sistem pendukung keputusan dalam kasus nyata
\end{abstract}

\section{Kata kunci: sistem pendukung keputusan, bobot aditif sederhana, kredit, aplikasi}

\section{Latar Belakang}

Perusahaan leasing berdiri dengan beragam layanan yang menawarkan berbagai pembiayaan. Dalam kegiatan menganalisis proses pemberian kredit, perusahaan membentuk divisi khusus yang disebut Credit Analyst (CA). Di dalam proses pemberian kredit, metode yang dilakukan oleh CA masih bersifat konvensional dan rentan terhadap penyalahgunaan wewenang. Selain itu, banyaknya pemohon kredit dengan keadaan ekonomi dan kriteria yang berbeda-beda juga menuntut kejelian individu dalam mengambil keputusan. Salah satu persoalan yang dihadapi dalam pemberian kredit adalah risiko macetnya pembayaran,yang menghambat laju perkembangan perusahaan, bahkan dalam kondisi ekstrim dapat menyebabkan kerugian. Untuk mencegah resiko terjadinya kredit macet, perusahaan harus memastikan kelayakan kesanggupan calon kreditur sebelum perjanjian kredit disetujui. Proses ini memerlukan analisis yang melibatkan banyak faktor penilaian. Penerapan Sistem Pendukung Keputusan (SPK)telah jamak digunakan oleh banyak instansi maupun perusahaan[7]. Mengacu pada persoalan menganalisis kemampuan membayar calon nasabah, suatu program aplikasi dapat dirancang sedemikian rupa untuk membantu proses penentuan kelayakan pemberian kredit kepada konsumen secara ilmiah dan dapat dipertanggungjawabkan. Metode yang dapat dipergunakan untuk keperluan tersebut adalah Simple Additive Weighting, salah satu jenis metode Fuzzy Multiple Attribute Decision Making (FMADM). Metode SAW juga dikenal sebagai metode penjumlahan terbobot. Konsep dasarnya adalah mencari penjumlahan 
terbobot dari rating kinerja setiap alternatif pada semua atribut.

\section{Tujuan penelitian}

Tujuan kegiatan penelitian yang dilaksanakan adalah merancang dan membangun suatu aplikasi penilaian kelayakan pemberian kredit yang menerapkan metode simple additive weighting (SAW) dalam analisisnya. Ini harus mencakup temuan penelitian. Hasilnya harus disajikan dalam urutan logis dengan penjelasan tahapan yang digunakan dalam pengujian dengan memuat informasi hasil dalam teks atau bentuk tabel dan grafik.

\section{Kredit}

Kredit berasal dari istilah latin credo yang berarti saya percaya, suatu kombinasi dari bahasa sansekerta cred yang artinya "kepercayaan" dan bahasa latin do yang artinya saya tempatkan. Memperoleh kredit berarti memperoleh kepercayaan dari orang lain atas penggunaan uang, barang atau jasa tertentu dengan syarat membayar kembali atau memberikan penggantian dalam jangka waktu yang telah dijanjikan. Sedangkan menurut Pasal 1 butir 11 Undang-Undang nomor 10 Tahun 1998 mengenai Perubahan Atas Undang-Undang Nomor 7 Tahun 1992 tentang Perbankan, "Kredit adalah penyediaan uang atau tagihan yang dapat dipersamakan dengan itu, berdasarkan persetujuan atau kesepakatan pinjam-meminjam antara bank dengan pihak lain yang mewajibkan pihak peminjam untuk melunasi utangnya setelah jangka waktu tertentu dengan pemberian bunga."[4]

\section{Pengertian, Jenis dan Tahapan Pengambilan Keputusan} Pengambilan keputusan merupakan alternatif tindakan untuk mencapai tujuan atau sasaran tertentu. Pengambilan keputusan dilakukan menggunakan pendekatan sistematis terhadap permasalahan melalui proses pengumpulan data menjadi informasi. Keputusan pada dasarnya dikelompokkan ke dalam dua jenis, yaitu keputusan terprogram dan keputusan tak terprogram[2]. Sedangkan proses pengambilan keputusan memiliki tahapan antara lain :

1. Tahap Pemahaman (Intelligent Phase)

2. Tahap Perancangan (Design Phase)

3. Tahap Pemilihan (Choice Phase)

4. Tahap implementasi (Implementation Phase)

\section{Sistem Pendukung Keputusan}

Sistem Pendukung Keputusan (SPK) atau Decision Support System (DSS), merupakan suatu sistem interaktif yang mendukung penentuan keputusan melalui alternatif-alternatif yang diperoleh dari hasil pengolahan data, informasi dan perancangan model. SPK adalah sistem berbasis model yang terdiri dari prosedur- prosedur dalam pemrosesan data beserta pertimbanganpertimbangannya, guna membantu manajer mengambil keputusan[7]. Agar tujuannya tercapai, sistem harus dibuat sederhana, robust, mudah untuk dikontrol, mudah beradaptasi pada hal-hal penting, serta mudah dikomunikasikan. SPK merupakan penggabungan sumber-sumber kecerdasan individu dengan kemampuan komponen untuk memperbaiki kualitas keputusan. SPK juga merupakan sistem informasi berbasis komputer untuk manajemen pengambilan keputusan yang menangani masalah masalah semi-struktur. Dengan pengertian-pengertian tersebut, dapat disimpulkan bahwa SPK bukan merupakan alat pengambilan keputusan, melainkan suatu sistem yang membantu para pengambil keputusan melengkapi informasi dari data yang telah diolah secara relevan, lalu digunakan untuk membuat keputusan atas suatu masalah secara cepat dan akurat.

\section{Karakteristik dan Komponen Penyusun SPK}

SPK memiliki beberapa karakteristik, yaitu :

1. Mendukung proses pengambilan keputusan yang berfokus pada manegement by perception.

2. Merupakan interface manusia dan mesin, dimana manusia sebagai pemegang kendali proses pengambil keputusan.

3. Dapat membantu pengambil keputusan dalam mengenali masalah terstruktur, semi struktur dan tak struktur.

4. Memiliki kapasitas dialog untuk memperoleh informasi sesuai kebutuhan.

5. Memiliki subsistem-subsistem yang terintegrasi sedemikian rupa sehingga dapat berfungsi sebagai satu kesatuan item.

6. Membutuhkan struktur data yang dapat melayani kebutuhan informasi bagi seluruh tingkatan manajemen.

SPK memiliki tiga subsistem utama dalam menentukan kapabilitas teknis sistem pendukung keputusan, antara lain :

1. Subsistem Manajemen Basis Data.

2. Subsistem Manajemen Basis Model..

3. Subsistem Dialog.

\section{Metode Fuzzy Multiple Attribute Decision Making}

Fuzzy Multiple Attribute Decision Making (FMADM) adalah suatu metode yang digunakan untuk mencari alternatif optimum dari sejumlah alternatif dengan kriteria tertentu. Inti dari FMADM adalah menentukan nilai bobot untuk setiap atribut, dilanjutkan dengan proses pemeringkatan diantara alternatif yang telah diberikan[1]. Terdapat tiga pendekatan dalam menemukan nilai bobot atribut, yaitu pendekatan subyektif, obyektif dan integrasi antara subyektif dan 
obyektif. Masing-masing pendekatan memiliki kelebihan dan kelemahan. Pada pendekatan subyektif, nilai bobot ditentukan berdasarkan subyektifitas para pengambil keputusan. Ini membuat beberapa faktor dalam proses pemeringkatan alternatif bisa ditetapkan secara bebas. Sedangkan pada pendekatan obyektif, nilai bobot dihitung secara matematis, mengabaikan aspek subyektifitas pengambil keputusan. Beberapa metode dapat digunakan untuk menyelesaikan masalah FMADM, antara lain :

1. Simple Additive Weighting (SAW)

2. Weighted Product (WP)

3. Elimination and Choise Expressing Reality (ELECTRE)

4. Technique for Order Preference by Similarity to Ideal Solution (TOPSIS)

5. Analytic Hierarchy Process (AHP)

\section{Metode Simple Additive Weighting}

Metode Simple Additive Weighting (SAW) merupakan metode Multiple Attribute Decision Making (MADM) yang paling sederhana dan paling banyak digunakan. Metode ini juga paling mudah diaplikasikan karena algoritmanya tidak rumit[2]. Metode SAW sering juga dikenal sebagai metode penjumlahan terbobot. Konsep dasarnya adalah mencari penjumlahan terbobot dari peringkat kinerja setiap alternatif pada semua atribut. Metode SAW membutuhkan proses normalisasi matriks keputusan $(X)$ ke suatu skala yang dapat diperbandingkan dengan semua rating alternatif yang ada. Berikut ini merupakan formula untuk mencari normalisasi dari metode $S A W$ :

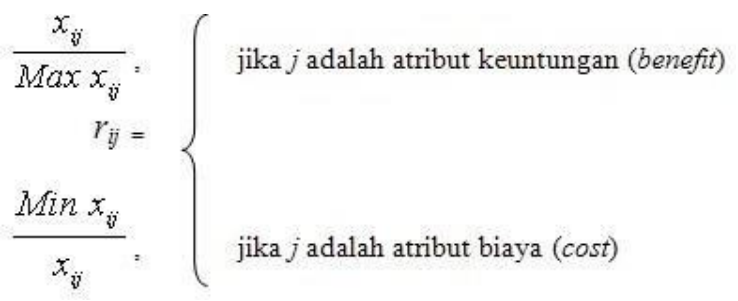

dimana:

$\mathrm{r}_{\mathrm{ij}} \quad$ : Peringkat kinerja ternormalisasi

Max : Nilai maksimum setiap baris dan kolom

Min : Nilai minimum setiap baris dan kolom

$\mathrm{X}_{\mathrm{ij}} \quad$ : Baris dan kolom dari matriks

Nilai $r_{i j}$ adalah peringkat kinerja ternormalisasi dari alternatif $A_{i}$ pada atribut $C_{j} ; i=1,2, \ldots, m$ dan $j=1,2, \ldots$, $n$.

Nilai preferensi untuk setiap alternatif $\left(V_{i}\right)$ dinayatakan dengan :

$$
V_{i}=\sum_{j=1}^{n} w_{j} r_{i j}
$$

dimana:

$v_{i}:$ Nilai akhir alternatif

$\mathrm{w}_{\mathrm{i}}$ : Bobot yang telah ditentukan

$r_{i j}$ : Normalisasi matriks

Nilai $v_{i}$ yang lebih besar mengindikasikan bahwa alternatif $a_{i}$ lebih dipilih dibandingkan dengan alternatif lainnya.

\section{Basis Data}

Basis data (database) adalah sekumpulan data yang memiliki hubungan secara logika dan diatur menurut susunan tertentu serta disimpan dalam media penyimpanan komputer. Basis data digunakan untuk memproses data untuk menghasilkan informasi tertentu. Basis data tidak hanya merupakan kumpulan berkas, namun juga sebagai pusat sumber data. Inti basis data adalah database management system (DBMS), yang membolehkan pembuatan, modifikasi, pembaharuan basis data, mendapatkan kembali[2]

\section{Unified Modeling Language}

Unified Modeling Language (UML) adalah bahasa pemodelan untuk sistem atau perangkat lunak yang berorientasi objek. Pemodelan digunakan untuk menyederhanakan permasalahan-permasalahan yang kompleks, sehingga mudah dipelajari dan dipahami[3]. Tujuannya adalah sebagai sarana analisis, pemahaman, visualisasi, komunikasi antar anggota tim pengembang, dokumentasi yang bermanfaat untuk menelaah perilaku perangkat lunak secara seksama, serta untuk melakukan pengujian terhadap perangkat lunak yang telah selesai dikembangkan. Dengan UML, dapat dibuat model bagi semua jenis aplikasi yang dapat berjalan pada piranti keras, sistem operasi dan jaringan, serta ditulis dalam bahasa pemrograman apapun. Karena menggunakan class dan operation dalam konsep dasarnya, UML dapat dituliskan dalam bahasa-bahasa berorientasi objek seperti C++, Java, C\# atau VB.NET[5]. UML mendefinisikan diagram-diagram sebagai berikut:

1. Use Case Diagram, menggambarkan fungsionalitas sistem yang merepresentasikan interaksi antara aktor dengan sistem.

2. Activity Diagram, menggambarkan alur aktivitas pada sistem yang dirancang.

3. ClassDiagram,spesifikasi yang menghasilkan sebuah objek dan merupakan inti dari pengembangan dan desain berorientasi objek.

4. SequenceDiagram,menggambarkan interaksi antar objek di dalam dan di sekitar sistem termasuk

Program Studi Teknik Informatika 
pengguna, tampilan, dan sebagainya, berupa pesan yang digambarkan terhadap waktu.

\section{Metode Penelitian}

\section{Tahapan Penelitian}

Secara garis besar, tahapan keseluruhan penelitian adalah sebagai berikut[7] :

1. Tahap persiapan.

2. Tahap perancangan. Pada tahap ini dilakukan perancangan sistem meliputi :

a. Penerapan metode Simple Additive Weighting, antara lain :

- Pemberian Bobot Per Kriteria

- Pemberian Nilai Crisp pada tiap Kriteria

- Penjabaran Alternatif pada tiap Kriteria

b. Pemodelan Sistem

c. Perancangan aplikasi

- Perancangan Tampilan

- Perancangan Database

3. Tahap Implementasi dan Pengujian.

4. Tahap penyelesaian.

Bagan alir tahapan penelitian ditunjukkan pada Gambar 1.

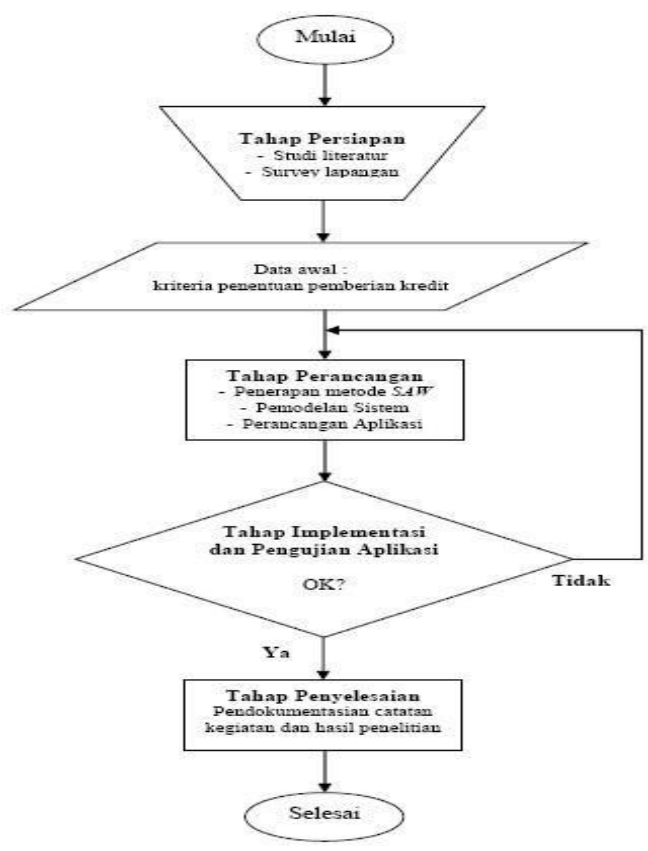

Lokasi Penelitian

Penelitian dilakukan di dua tempat, yakni :

1. Kantor Adira Finance, Jl. Bambu 2 Blok A No. 12 Medan.

2. Kampus Universitas Prima Indonesia:

- Perpustakaan : studi literatur penelitian internal terdahulu.
- Laboratorium Komputer : perancangan dan pembuatan aplikasi.

\section{Rancangan Penelitian}

Metode SPK yang digunakan adalah metode Simple Additive Weighting (SAW). Metode SAW sering juga dikenal sebagai metode penjumlahan terbobot. Konsep dasar metode SAW adalah mencari penjumlahan terbobot dari rating kinerja pada setiap alternatif pada semua atribut.

Penentuan persetujuan permohonan kredit pada rancangan didasarkan atas penilaian atas kedisiplinan pemohon kredit, uang muka, penghasilan, jaminan, dan status tempat tinggal. Langkah awal metode SAW adalah pemberian nilai bobot pada setiap kriteria. Pembobotan kelima kriteria tersebut diperlihatkan dalam tabel berikut.

\begin{tabular}{|c|c|c|}
\hline Kode Kriteria & Nama Kriteria & $\begin{array}{c}\text { Nilai } \\
\text { Bobot }\end{array}$ \\
\hline C1 & Kedisiplinan & 25 \\
\hline C2 & Uang Muka & 10 \\
\hline C3 & $\begin{array}{c}\text { Penghasilan Per } \\
\text { Bulan }\end{array}$ & 45 \\
\hline C4 & Jaminan Kredit & 10 \\
\hline C5 & $\begin{array}{c}\text { Status Tempat } \\
\text { Tinggal }\end{array}$ & 10 \\
\hline
\end{tabular}

Metode SAW membutuhkan proses normalisasi matriks keputusan $(X)$ ke suatu skala yang dapat diperbandingkan dengan semua peringkat alternatif yang ada. Dari kriteria sebelumnya, dibuat tingkatan kriteria berdasarkan alternatif (pemohon kredit) yang telah ditentukan ke dalam nilai crisp. Rating kecocokan setiap alternatif pada setiap kriteria dapat dilihat pada tabel-tabel berikut.

\begin{tabular}{|c|c|c|}
\hline Kriteria & Kriteria Pemohon & $\begin{array}{l}\text { Nilai } \\
\text { Crisp }\end{array}$ \\
\hline \multirow{5}{*}{$\begin{array}{l}\text { Kedisiplinan } \\
\text { (C1) }\end{array}$} & $\begin{array}{c}\text { Ada riwayat kredit } \\
\text { macet }\end{array}$ & 10 \\
\hline & $\begin{array}{c}\text { History kredit lunas } \\
\text { dengan banyak } \\
\text { tunggakan }\end{array}$ & 20 \\
\hline & Belum pernah kredit & 40 \\
\hline & $\begin{array}{c}\text { History kredit lunas } \\
\text { dengan sedikit } \\
\text { tunggakan }\end{array}$ & 80 \\
\hline & $\begin{array}{c}\text { History kredit lunas } \\
\text { dan lancar }\end{array}$ & 100 \\
\hline Kriteria & Kriteria Pemohon & $\begin{array}{l}\text { Nilai } \\
\text { Crisp }\end{array}$ \\
\hline
\end{tabular}




\begin{tabular}{|l|c|c|}
\hline \multirow{4}{*}{$\begin{array}{l}\text { Uang } \\
\text { Muka }\end{array}$} & DP $<15 \%$ dari harga & 20 \\
\cline { 2 - 3 }$(\mathrm{C} 2)$ & DP $16-20 \%$ dari harga & 40 \\
\cline { 2 - 3 } & DP $21-25 \%$ dari harga & 60 \\
\cline { 2 - 3 } & DP $26-30 \%$ dari harga & 80 \\
\cline { 2 - 3 } & DP $>30 \%$ dari harga & 100 \\
\hline
\end{tabular}

\begin{tabular}{|c|c|c|}
\hline Kriteria & Kriteria Pemohon & Nilai Crisp \\
\hline \multirow{4}{*}{$\begin{array}{c}\text { Penghasil } \\
\text { an } \\
\text { (C3) }\end{array}$} & $\begin{array}{c}\text { Penghasilan <= 1 juta } \\
\text { juta sampailan 2 juta }\end{array}$ & 30 \\
\cline { 2 - 3 } & $\begin{array}{c}\text { Penghasilan antara 2 } \\
\text { juta sampai 5 juta }\end{array}$ & 60 \\
\cline { 2 - 3 } & $\begin{array}{c}\text { Penghasilan antara 5 } \\
\text { juta sampai 10 juta }\end{array}$ & 80 \\
\cline { 2 - 3 } & $\begin{array}{c}\text { Penghasilan di atas } \\
10 \text { juta }\end{array}$ & 100 \\
\hline
\end{tabular}

\begin{tabular}{|c|c|c|}
\hline Kriteria & Kriteria Pemohon & Nilai Crisp \\
\hline \multirow{2}{*}{$\begin{array}{c}\text { Jaminan } \\
\text { (C4) }\end{array}$} & BPKB motor & 50 \\
\cline { 2 - 3 } & BPKB mobil & 75 \\
\cline { 2 - 3 } & Sertifikat tanah & 100 \\
\hline
\end{tabular}

\begin{tabular}{|c|c|c|}
\hline Kriteria & Kriteria Pemohon & Nilai Crisp \\
\hline \multirow{5}{*}{$\begin{array}{c}\text { Status } \\
\text { Tempat } \\
\text { Tinggal } \\
\text { (C5) }\end{array}$} & Kost / Kontrak & 20 \\
\hline & KPR & 40 \\
\hline & $\begin{array}{c}\text { Rumah dinas / } \\
\text { perusahaan }\end{array}$ & 60 \\
\hline & $\begin{array}{c}\text { Rumah orang tua / } \\
\text { keluarga }\end{array}$ & 80 \\
\hline & Rumah milik sendiri & 100 \\
\hline
\end{tabular}

Berdasarkan kriteria dan peringkat kecocokannya,alternatif pada setiap kriteria dikonversike dalam nilai crisp. Sebagai contoh, misalkan terdapat delapan pemohon kredit dengan data yangdiperlihatkandalam pada tabel berikut :

\begin{tabular}{|c|c|c|c|c|c|}
\hline \multirow{2}{*}{ Nama Pemohon } & \multicolumn{5}{|c|}{ Kriteria } \\
\cline { 2 - 6 } & C1 & C2 & C3 & C4 & C5 \\
\hline Fendi & 80 & 40 & 60 & 50 & 100 \\
\hline Jonny & 10 & 20 & 30 & 50 & 20 \\
\hline William & 40 & 40 & 80 & 75 & 80 \\
\hline Veronica & 80 & 80 & 60 & 75 & 100 \\
\hline Debbie & 40 & 60 & 60 & 50 & 60 \\
\hline Edy & 20 & 60 & 60 & 50 & 60 \\
\hline Julius & 40 & 40 & 50 & 75 & 40 \\
\hline Didi & 20 & 40 & 80 & 75 & 60 \\
\hline
\end{tabular}

Matriks kriterianya adalah :

$$
\mathrm{X}=\left(\begin{array}{lllll}
80 & 40 & 60 & 50 & 100 \\
10 & 20 & 30 & 50 & 20 \\
40 & 40 & 80 & 75 & 80 \\
80 & 80 & 60 & 75 & 100 \\
40 & 60 & 60 & 50 & 60 \\
20 & 60 & 60 & 50 & 60 \\
40 & 40 & 50 & 75 & 40 \\
20 & 40 & 80 & 75 & 60
\end{array}\right)
$$

Normalisasi terhadap matriks selanjutnyadilakukan dengan menghitung nilai peringkat kinerja ternormalisasi $\left(r_{i j}\right)$ dari alternatif $A_{i}$ pada atribut $C_{j}$ berdasarkan persamaan yang disesuaikan dengan jenis atributnya.Dengan menetapkan semua atribut berupa keuntungan (benefit), maka nilai crisp $\left(\mathrm{X}_{\mathrm{ij}}\right)$ dari setiap kolom dibagi dengan crisp maksimum adalah :

$$
R_{i j}=\frac{C_{i j}}{\operatorname{Max} C_{i j}}
$$

Dengan nilai maksimum crispsebesar 100 , rasio kriteria dalam matriks normalisasi (R):

$$
\mathrm{R}=\left(\begin{array}{lllll}
0.8 & 0.4 & 0.6 & 0.5 & 1 \\
0.1 & 0.2 & 0.3 & 0.5 & 0.2 \\
0.4 & 0.4 & 0.8 & 0.75 & 0.8 \\
0.8 & 0.8 & 0.6 & 0.75 & 1 \\
0.4 & 0.6 & 0.6 & 0.5 & 0.6 \\
0.2 & 0.6 & 0.6 & 0.5 & 0.6 \\
0.4 & 0.4 & 0.5 & 0.75 & 0.4 \\
0.2 & 0.4 & 0.8 & 0.75 & 0.6
\end{array}\right)
$$

Sedangkan matriks nilai bobot $\mathrm{W}$ adalah:

$$
\mathrm{W}=\left(\begin{array}{l}
25 \\
10 \\
45 \\
10 \\
10
\end{array}\right)
$$

Untuk mendapatkan hasil penilaian, matriks $\mathrm{R}$ dikalikan dengan nilai $\mathrm{W}$, sehinggadiperoleh :

$$
\begin{aligned}
& \mathrm{V} 1=25(0.8)+10(0.4)+45(0.6)+10(0.5)+10(1)=66 \\
& \mathrm{~V} 2=25(0.1)+10(0.2)+45(0.3)+10(0.5)+10(0.2)=25 \\
& \mathrm{~V} 3=25(0.4)+10(0.4)+45(0.8)+10(0.75)+10(0.8)=65.5 \\
& \mathrm{~V} 4=25(0.8)+10(0.8)+45(0.6)+10(0.75)+10(1)=72.5 \\
& \mathrm{~V} 5=25(0.4)+10(0.6)+45(0.6)+10(0.5)+10(0.6)=54 \\
& \text { V6 }=25(0.2)+10(0.6)+45(0.6)+10(0.5)+10(0.6)=49 \\
& \text { V7 }=25(0.4)+10(0.4)+45(0.5)+10(0.75)+10(0.4)=48 \\
& \text { V8 }=25(0.2)+10(0.4)+45(0.8)+10(0.75)+10(0.6)=58.5
\end{aligned}
$$

Hasil perhitungan dan pengurutan nilai akhir $\mathrm{V}$ adalah sebagai berikut : 

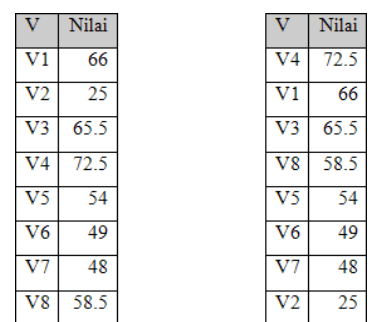

Dengan nilai kelayakan berada di antara nilai 61-100, maka diperoleh penetapan penilaian untuk setiap pemohon sebagai berikut :

\begin{tabular}{|l|r|r|r|r|r|r|r|r|r|r|r|l|}
\hline Kode & C1 & $\begin{array}{r}\text { R1x } \\
\text { W1 }\end{array}$ & C2 & $\begin{array}{r}\text { R2x } \\
\text { W2 }\end{array}$ & C3 & $\begin{array}{r}\text { R3x } \\
\text { W3 }\end{array}$ & C4 & $\begin{array}{r}\text { R4x } \\
\text { W4 }\end{array}$ & C5 & $\begin{array}{r}\text { R5x } \\
\text { W5 }\end{array}$ & V & Status \\
\hline Fendi & 80 & 20 & 40 & 4 & 60 & 27 & 50 & 5 & 100 & 10 & 66 & Layak \\
\hline Jonny & 10 & 2.5 & 20 & 2 & 30 & 13.5 & 50 & 5 & 20 & 2 & 25 & Tidak Layak \\
\hline William & 40 & 10 & 40 & 4 & 80 & 36 & 75 & 7.5 & 80 & 8 & 66 & Layak \\
\hline Veronica & 80 & 20 & 80 & 8 & 60 & 27 & 75 & 7.5 & 100 & 10 & 73 & Layak \\
\hline Debbie & 40 & 10 & 60 & 6 & 60 & 27 & 50 & 5 & 60 & 6 & 54 & Tidak Layak \\
\hline Edy & 20 & 5 & 60 & 6 & 60 & 27 & 50 & 5 & 60 & 6 & 49 & Tidak Layak \\
\hline Julius & 40 & 10 & 40 & 4 & 50 & 22.5 & 75 & 7.5 & 40 & 4 & 48 & Tidak Layak \\
\hline Didi & 20 & 5 & 40 & 4 & 80 & 36 & 75 & 7.5 & 60 & 6 & 59 & Tidak Layak \\
\hline
\end{tabular}

Pada tahap perancangan, pemodelan yang digunakan adalah sebagai berikut :

1. Use case diagram.

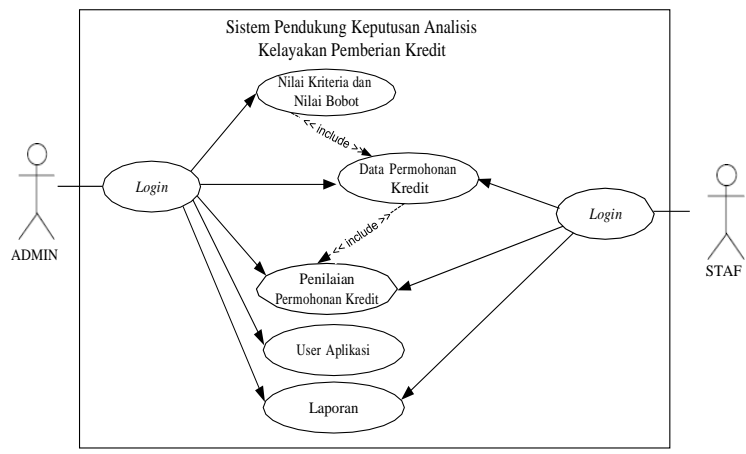

2. Sequence diagram sistem analisis kredit.

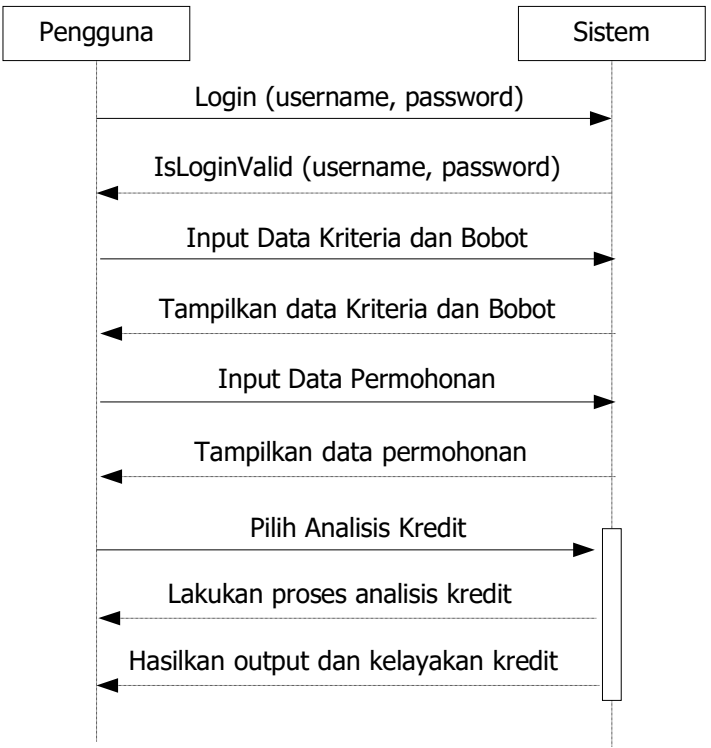

3. Activity diagram.

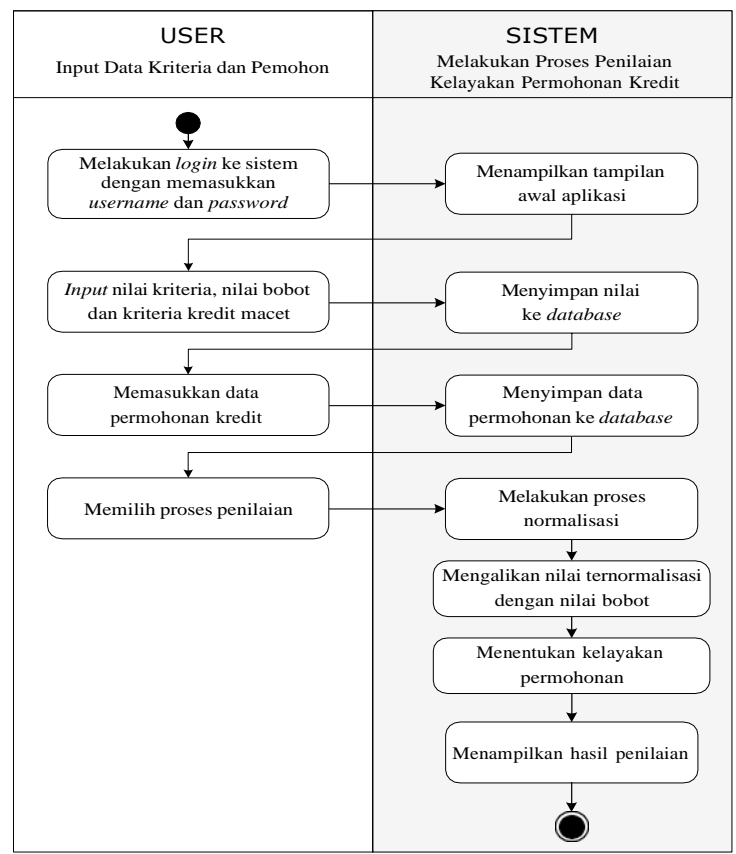

4. Class diagram sistem analisis kredit.

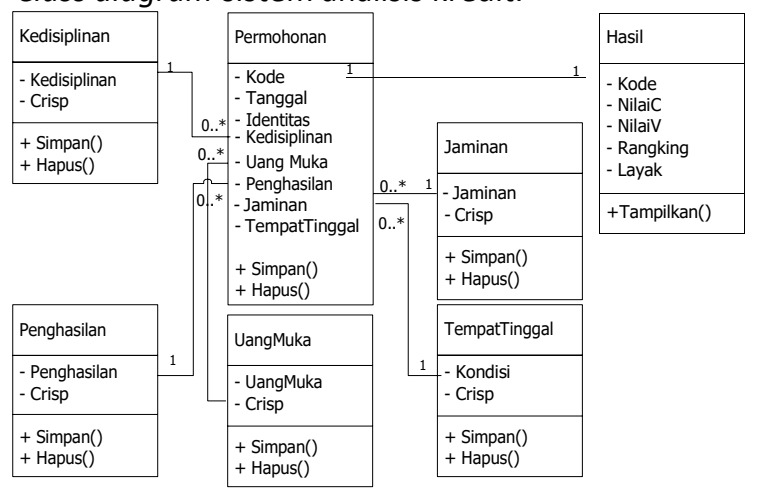

Program Studi Teknik Informatika 


\section{Hasil}

Implementasi perancangan aplikasi menggunakan metode Simple Additive Weighting (SAW) adalah sebagai berikut.

1. Pada saat aplikasi dijalankan, form Login ditampilkan. Pengguna mengisi kotak username dan password yang tersedia.

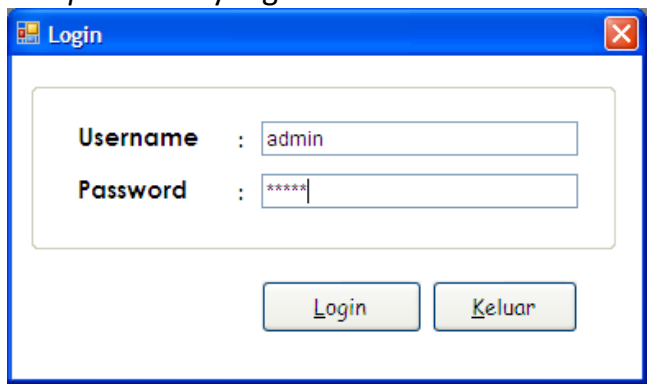

Setelah pengguna berhasil login ke dalam sistem, form Kriteria Kedisipinan (C1) ditampilkan.

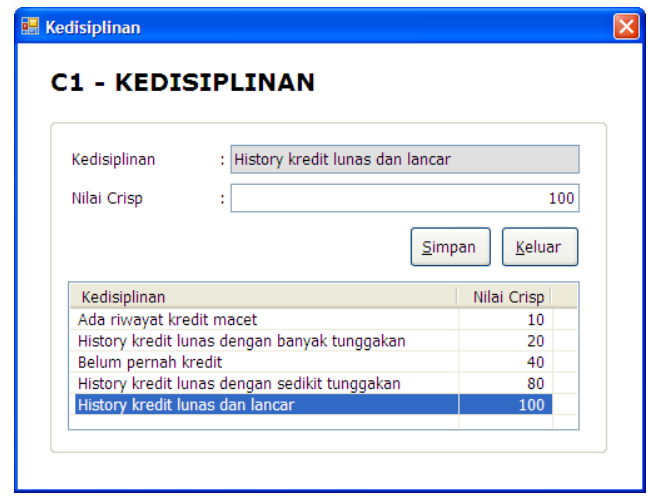

2. Jika pengguna memilih menu [Kriteria dan Bobot] - [Kriteria C2 - Uang Muka], form Kriteria Uang Muka ditampilkan. Pada form ini, nilai crispkriteria dapat diubah-ubah.

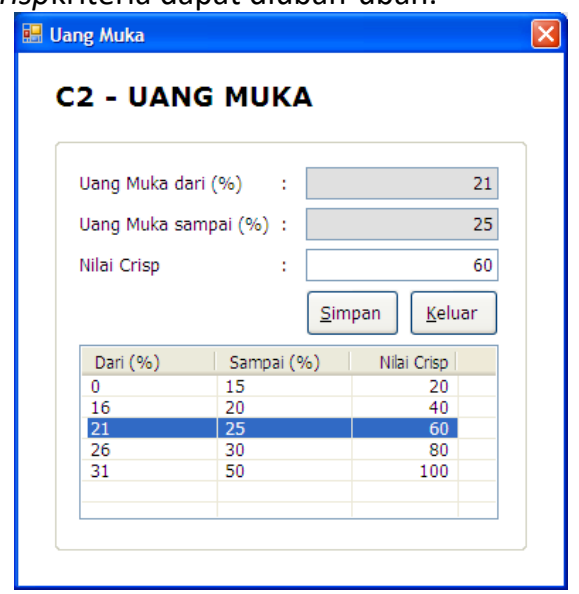

3. Jika pengguna memilih menu [Kriteria dan Bobot] - [Kriteria C3 - Penghasilan], form Kriteria
Penghasilan ditampilkan. Pada form ini, nilai crispkriteria dapat diubah-ubah.

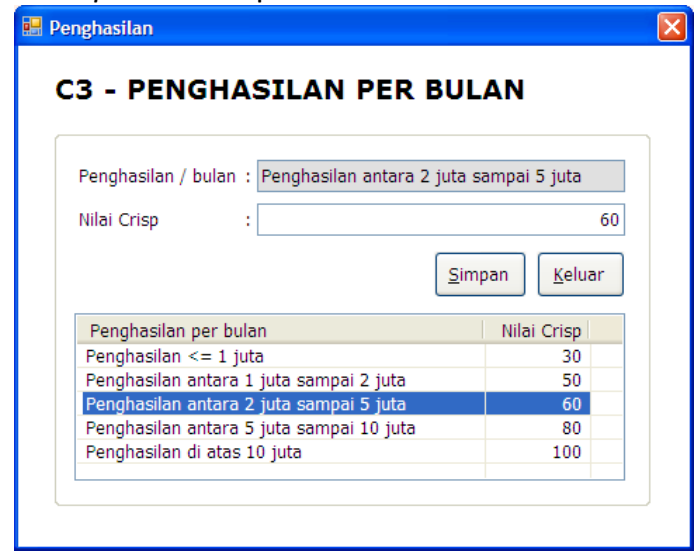

4. Jika pengguna memilih menu [Kriteria dan Bobot] - [Kriteria C4 - Jaminan], formKriteria Jaminan ditampilkan. Pada form ini, nilai crispkriteria dapat diubah-ubah.

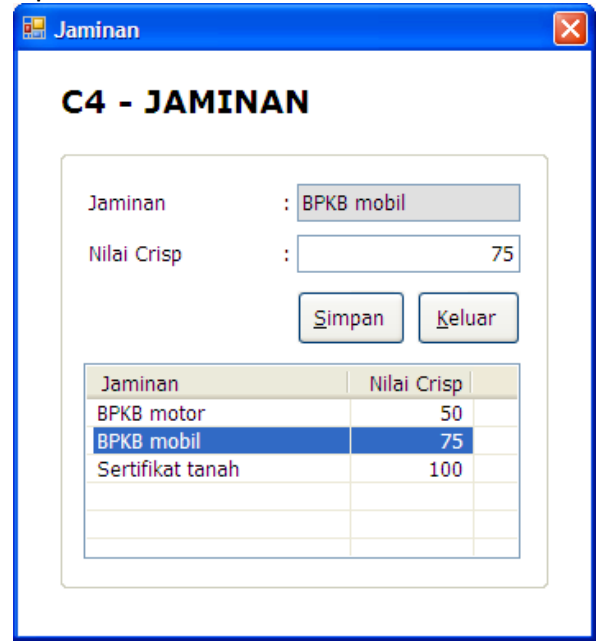

5. Jika pengguna memilih menu [Kriteria dan Bobot] - [Kriteria C5 - Tempat Tinggal], formKriteria Tempat Tinggal ditampilkan. Pada form ini, nilai crisp kriteria dapat diubah-ubah.

Program Studi Teknik Informatika 


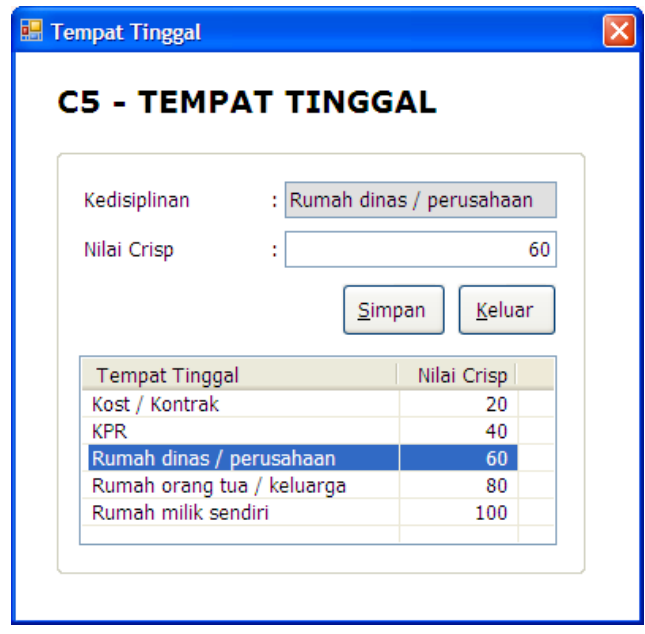

6. Jika pengguna memilih menu [Kriteria dan Bobot] - [Bobot Kriteria], form Bobot Kriteria ditampilkan. Pada form ini, nilai bobot kriteria dapat diubah-ubah.

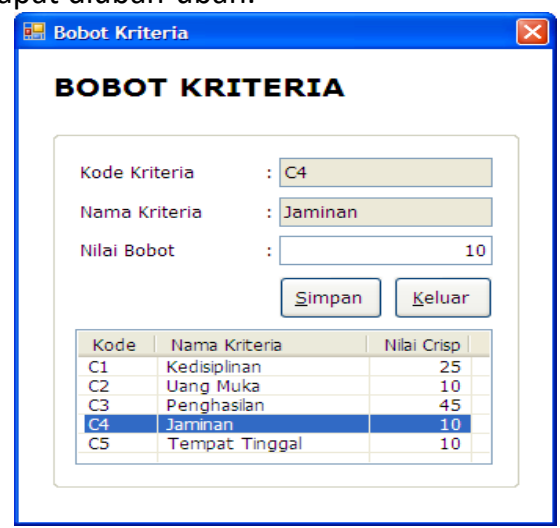

7. Bila memilih menu [Proses] - [Input Data Permohonan Kredit], maka formInput Permohonan Kredit ditampilkan. Pada form ini, pengguna dapat memasukkan permohonan kredit.

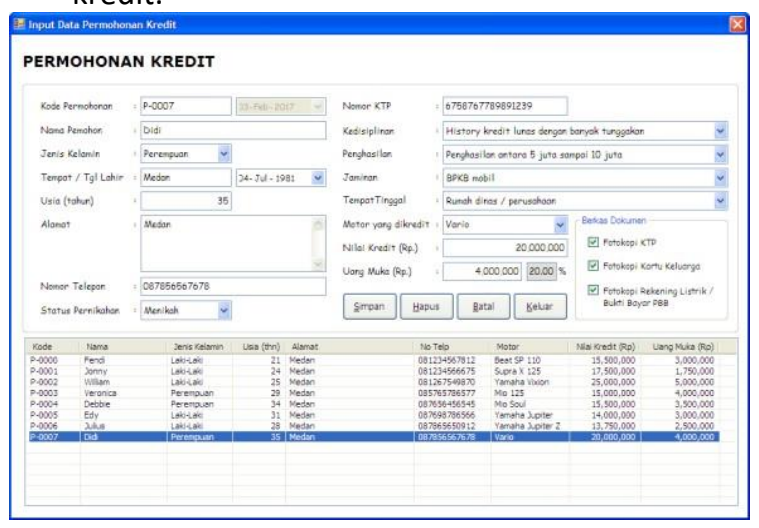

8. Untuk memproses penilaian terhadap permohonan kredit, menu [Proses] - [Proses Penilaian Permohonan Kredit] dapat dipilih, selanjutnyaform Penilaian ditampilkan.

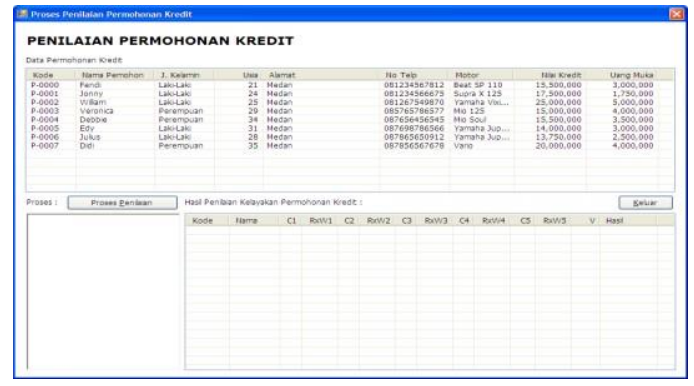

9. Tombol Proses Penilaiandapat ditekan untuk memulai proses penilaian.

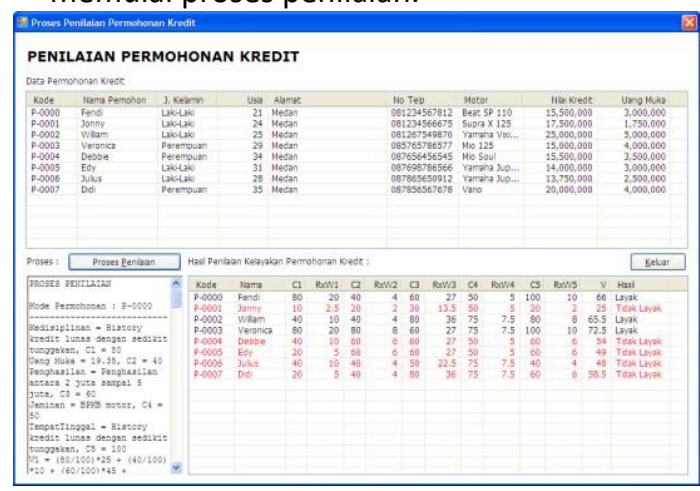

10. Untuk memasukkan atau mengubah data pengguna yang dapat melakukan login, menu [Data User] dipilih dan form Daftar Userditampilkan.

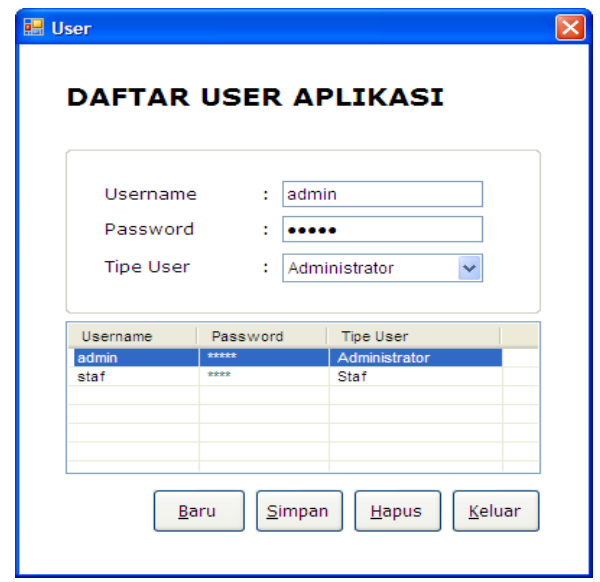

11. Untuk melihat laporan permohonan kredit, pilih menu [Laporan] - [Laporan Permohonan Kredit], dan form Filter Laporan per Tanggal ditampilkan.

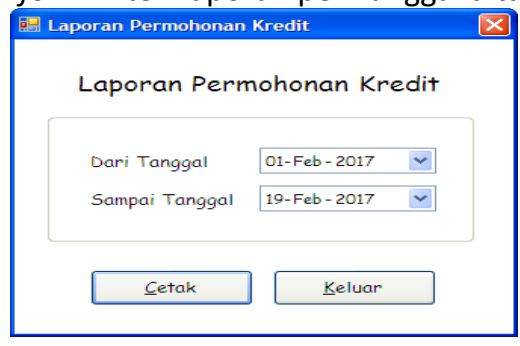


12. Jika rangetanggal dipilih, dan tombol Cetak ditekan, laporan permohonan kredit ditampilkan.Pengguna dapat melihat semua permohonan kredit yang pernah dilakukan.

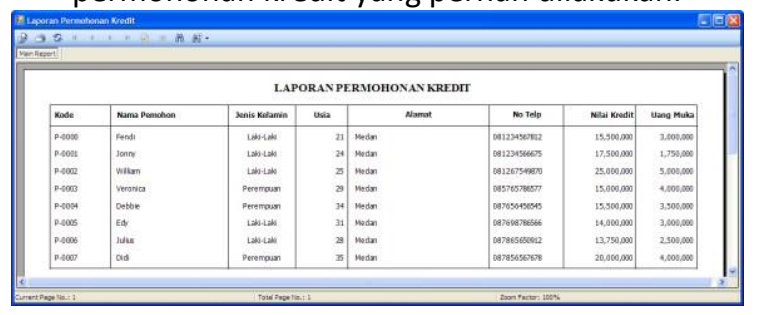

13. Untuk melihat laporan permohonan kredit bulanan, pengguna dapat memilih menu [Laporan] - [Laporan Permohonan Kredit (Bulanan)].

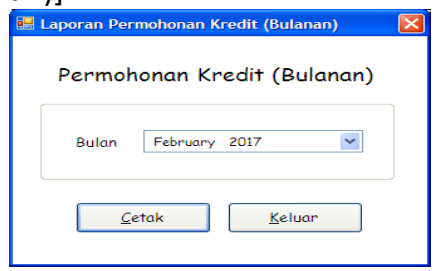

14. Jika pengguna memilih periodebulanan lalu menekan tombol Cetak, laporan permohonan kredit bulanan ditampilkan.

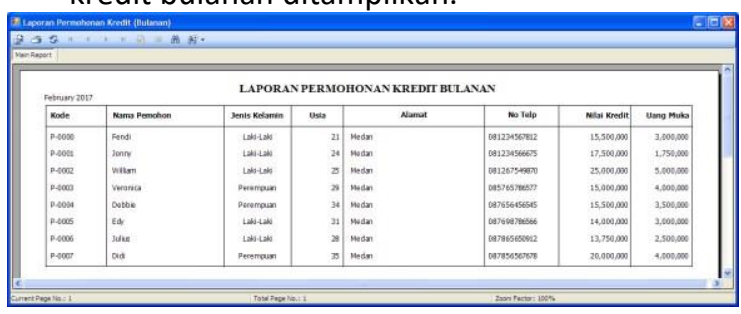

15. Untuk melihat laporan keputusan kredit, menu [Laporan] - [Laporan Keputusan Kredit] dan range tanggal laporan dapat dipilih. Dengan menekan tombol Cetak, laporan keputusan kredit ditampilkan. Pada laporan ini, pengguna dapat melihat hasil penilaian semua permohonan kredit, apakah layak atau tidak untuk disetujui.

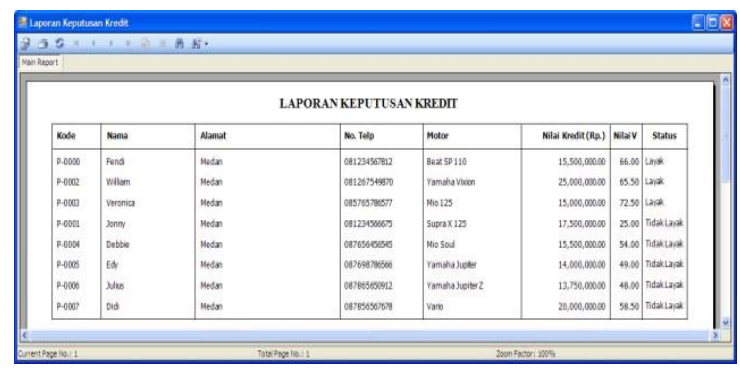

Untuk keluar dari aplikasi, pengguna dapat menekan tombol menu Keluar.

Program Studi Teknik Informatika

Universitas Prima Indonesia (UNPRI) Medan

\section{Kesimpulan dan Saran}

Kesimpulan

Berdasarkan hasil penelitian yang diperoleh, dapat

disimpulkan beberapa hal sebagai berikut :

1. Aplikasi untuk membantu proses penilaian kelayakan pemberian kredit dengan menggunakan metode SAW telah diselesaikan dan berjalan dengan baik.

2. Pengguna dapat menyesuaikan nilai crisp dan nilai bobot dari masing-masing kriteria serta kriteria kredit yang bermasalah di dalam aplikasi, sehingga proses penilaian dapat disesuaikan dengan kebutuhan.

\section{Saran}

Saran untuk pengembangan aplikasi lebih lanjut :

1. Aplikasi serupa pada mobileplatformdimungkinkan sebagai pengembangan.

2. Penambahan fitur di dalam aplikasi dapat dilakukan dengan opsi penyesuaian kriteria pada proses penilaian oleh pengguna.

3. Metode-metode yang lain seperti AHP, TOPSIS, atau ELECTRE, dapat dijadikan sebagai pembanding untuk mengetahui kelebihan dan kelemahan dari masingmasing metode tersebut.

\section{Daftar Pustaka}

[1] Kendall, K.E. dan Kendall, J.E. 2012. Analisis dan Perancangan Sistem. PT Prenhallindo, Jakarta.

[2] Oktaputra dan Noersasongko .2014. Sistem Pendukung Keputusan Kelayakan Pemberian Kredit Motor Pada Perusahaan Leasing HD Finance. Skripsi. Universitas Dian Nuswantoro, Semarang.

[3] Dharwiyanti dan Wahono (2013),"Pengantar Unified Modeling Language", Kuliah IlmuKomputer.com.

[4] Hariyani, I. (2010), "Restrukturisasi dan Penghapusan Kredit Macet". Elex Media, Jakarta [Online]

(https://books.google.co.id/books?id=weeCdyyzl WOC),

accessed on December 15th, 2016.

[5] Nugroho, A. (2010), "Rekayasa Perangkat Lunak Berorientasi Objek dengan Metode USDP (Unified Software Development Process)", Andi offset Yogyakarta.

[Online] (https://books.google.co.id/books?id=CBOIKsa9cN EC), accessed on February 1 st, 2017.

[6] Rachmat (2014), "Perancangan Aplikasi Penghitungan dan Penyaluran Zakat Mal", Informasi dan Teknologi IImiah, ISSN:2339-210X, Volume IV, Nomor 3. 
[7] Setiawan dkk. (2012), "Implementasi Sistem Pendukung Keputusan pada Supplier Furniture Menggunakan Model Promethee", Fakultas Teknologi Industri Kristen Petra, Surabaya. 